\title{
PERTUMBUHAN DAN HASIL JAGUNG (ZEA MAYS L.) PADA SISTEM AGROFORESTRI DENGAN GAHARU (AQUILARIA MALACCENSIS) DI DESA JAHARUN B, KECAMATAN GALANG, KABUPATEN DELI SERDANG, SUMATERA UTARA
}

\section{THE GROWTH AND PRODUCTION OF CORN (ZEA MAYS L.) IN AGROFORESTRY SYSTEM IN JAHARUN VILLAGE, GALANG SUBDISTRICT, DELI SERDANG DISTRICT, NORTH SUMATERA}

\author{
Lily Novianty*, Tika Rahma Yunita \\ Program Studi Budidaya Pertanian, Universitas Nahdatul Ulama Sumatera Utara, Indonesia \\ Diterima: 29-06-2020; Disetujui: 16-07-2020; Dipublish: 30-07-2020 \\ *Corresponding Email: lily.novianty90@gmail.com
}

\begin{abstract}
Abstrak
Penelitian bertujuan untuk menganalisis respon fisiologis, pertumbuhan dan produksi jagung berdasarkan agroforestri gaharu, dan untuk menganalisis pengaruh budidaya jagung terhadap pertumbuhan diameter batang gaharu. Penelitian ini menggunakan desain eksperimen faktorial, dengan 2 perlakuan dan 3 ulangan, perlakuan pertama adalah sistem penanaman jagung (monokultur dan agroforestri), dan varietas jagung. Penelitian ini menggunakan dua varietas jagung (varietas lokal dan varietas komersial). Setiap kombinasi perlakuan terdiri dari 24 tanaman, sehingga \pm 288 tanaman jagung diperoleh. Hasil penelitian menunjukkan bahwa ada penurunan pertumbuhan jagung yang ditanam dalam monokultur dan ditanami gaharu. Jagung yang ditanam di lahan gaharu menunjukkan pertumbuhan terhambat, ditunjukkan oleh rendahnya nilai tinggi tanaman, jumlah daun, dan diameter batang dan berbeda nyata dari tinggi tanaman, jumlah daun, dan diameter batang jagung yang ditanam dalam monokultur. Hasil uji jaringan menunjukkan bahwa nilai serapan unsur $\mathrm{N}, \mathrm{P}, \mathrm{K}, \mathrm{Na}$, dan $\mathrm{Mg}$ tidak berbeda, baik jagung dalam monokultur maupun lahan jagung yang ditanam di lahan gaharu.
\end{abstract}

Kata Kunci: Agroforestri, gaharu, jagung

\section{Abstract}

This study aims was to analyze physiological responses, growth and production of corn based on agarwood agroforestry, and to analyze the effect of corn cultivation on the growth of agarwood stem diameter. This study used factorial experimental design, with 2 treatments and 3 replications, the first treatment was corn planting systems (monoculture and agroforestry), and corn varieties. This study uses two varieties of corn (local varieties and commercial varieties). Each treatment combination consisted of 24 plants, so that \pm 288 maize plants were obtained. The results showed that there was a decrease in the growth of corn grown in monoculture and planted with gaharu. Maize grown in agarwood land showed stunted growth, indicated by the low value of plant height, number of leaves, and stem diameter and significantly different from plant height, number of leaves, and diameter of corn stems grown in monoculture. Tissue test results showed that the absorption values of $N, P, K, N a$ and $M g$ elements were not different, either corn in monoculture or corn fields planted in agarwood land.

Keywords: Learning Style, Activities, Critical Thinking Ability

How to Cite: Novianty, L., Yunita, T.R. (2020). Pertumbuhan Dan Hasil Jagung ( Zea mays L.) Pada Sistem Agroforestri Dengan Gaharu (Aquilaria malaccensis) Di Desa Jaharun B, Kecamatan Galang, Kabupaten Deli Serdang, Sumatera Utara. Journal of Natural Sciences. Vol 1 (2): 72-83

(C) (i)




\section{PENDAHULUAN}

Laju pertambahan penduduk yang sangat cepat menimbulkan masalah yang kompleks akhir-akhir ini. Peningkatan jumlah penduduk diikuti oleh peningkatan kebutuhan pangan, sandang, papan/perumahan dan lain-lain. Lahan yang memadahi diperlukan untuk penyediaan kebutuhan tersebut, terutama untuk budidaya pertanian. Pengolahan lahan yang tidak ramah lingkungan dapat mempercepat terjadinya degradasi kesuburan tanah (Prasetyo 2004). Penanaman tanaman pertanian di areal hutan atau perkebunan yang dikenal dengan sistem agroforestri merupakan alternatif pemecahan masalah yang ada.

Spesies Aquilaria malaccensis adalah tanaman penghasil gaharu berkualitas terbaik, sebagai akibat dari proses infeksi yang terjadi secara alami atau buatan pada pohon gaharu. Eksploitasi gaharu yang disertai pembalakan hutan mengakibatkan kelangkaan pohon gaharu dan hilangnya pohon (genotipe) unggul. Akibat kelangkaan tersebut menurut Balitbanghut (2006) semua jenis Aquilaria terdaftar pada CITES Apendiks II sebagai tumbuhan langka. Jenis tanaman gaharu ini sangat mahal harganya, yaitu Rp 15.000.000 per kg. Kelangkaan jenis pohon penghasil gaharu tersebut harus diimbangi dengan usaha pengembangan dan budidaya tanaman penghasil gaharu, baik secara monokultur maupun sistem agroforestri.

Indonesia salah negara penghasil sumber karbohidrat penting yaitu jagung, namun permintaan lebih tinggi dibandingkan dengan produksinya. Salah satu jenis tanaman pangan yang penting untuk dikembangkan adalah jagung. Permasalahn swasembada jagung adalah luas tanaman jagung khususnya di Kabupaten Deli Serdang semakin menyempit pada tahun 2015 diperkirakan 18.236 ha, sedangkan luas tanaman jagung di Kecamatan Galang 45 ha. Hasil produksi jagung di Kabupaten Deli Serdang pada tahun 2015 diperkirakan 19.521 ton, sedangkan untuk produksi jagung di Kecamatan Galang pada tahun 2015 diperkirakan hanya 150 ton (BPS 2015). Salah satu strategi perluasan areal tanam jagung adalah dengan menerapkan sistem agroforestri.

Beberapa lahan masyarakat di Kabupaten Deli Serdang masih menerapkan pola monokultur untuk tanaman gaharu. Produksi tanaman sela yang ditanam oleh petani 
diantara tegakan pohon di Kabupaten Deli Serdang masih sangat rendah. Hal ini menunjukkan bahwa optimalisasi lahan belum sepenuhnya diterapkan oleh masyarakat Kabupaten Deli Serdang. Penelitian mengenai pertumbuhan dan produksi jagung berbasiskan agroforestri gaharu dapat menjadi salah satu upaya optimalisasi pemanfaatan lahan, dan hasilnya diharapkan bisa menjadi rekomendasi bagi petani hutan rakyat dan pemerintah daerah dalam pengembangan jagung tersebut di hutan rakyat gaharu Kabupaten Deli Serdang.

\section{METODE PENELITIAN}

Penelitian dilaksanakan mulai bulan Maret 2018 sampai Juni 2018 di lahan Kecamatan Galang, Kabupaten Deli Serdang, Sumatera Utara, Pusat Penelitian Kelapa Sawit, Medan.

Penelitian dilakukan di dua lahan yaitu lahan pertumbuhan gaharu berbasis agroforestry dengan jagung dan lahan pertanaman jagung monokultur. Benih jagung yang digunakan adalah benih yang memenuhi persyaratan genetika, fisik dan fisiologis.

Terdapat tiga varietas jagung yang digunakan dalam penelitin ini. Varietas lokal yaitu jagung IPB J1 (jagung ungu), jagung IPB J2 (jagung merah) dan varietas komersil jagung Bonanza F1 (jagung kuning). Pemilihan lahan untuk agroforestry yaitu gaharu dengan umur yang seragam yaitu 3 tahun dengan tinggi \pm 4 m dan dengan jarak tanam $3 \times 3 \mathrm{~m}$.

Penyiapan lahan dilakukan 2 minggu sebelum penanaman, meliputi pembersihan lahan, pengolahan lahan, penyemprotan herbisida, dan pembuatan lubang tanam. Persiapan lahan dilakukan dengan membuat lubang tanam jagung, dengan jarak tanam $70 \mathrm{~cm}$ x $40 \mathrm{~cm}$. Jarak tanam $70 \mathrm{~cm}$ x $40 \mathrm{~cm}$ meningkatkan jumlah daun, diameter batang, diameter tongkol, dan produksi pertanaman (Tyrida dkk., 2013). Penanaman jagung dilakukan dengan luasan lahan 1,4 m x $5 \mathrm{~m}$, yang ditanami oleh \pm 24 tanaman. Berikut desain plot percobaan : 


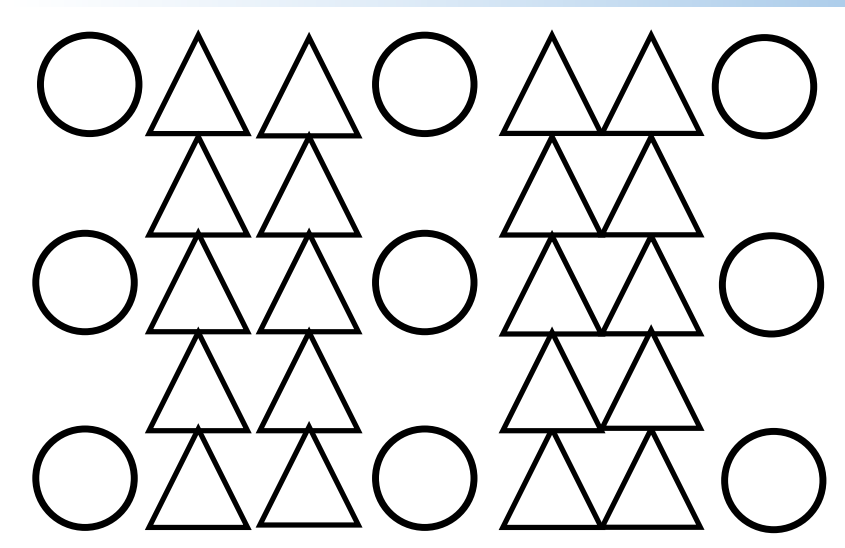

$$
\begin{aligned}
& \triangle=\text { jagung } \\
& \bigcirc=\text { gaharu }
\end{aligned}
$$

Seminggu setelah penanaman, dilakukan penyiangan pada biji yang tidak berkecambah. Penyiraman, dan perawatan tanaman dilakukan selama masa pertumbuhan, dengan menghilangkan gulma dari lahan pertanaman, dan juga memantau dan mengendalikan populasi hama dan penyakit yang menyerang saat penanaman.

Tanaman dipanen dengan memanen tongkol jagung pada tanaman yang telah masak fisiologis. Tanaman jagung dapat dipanen dengan umur 3-4 bulan.

\section{Analisis jaringan tanaman}

Analisis jaringan tanaman dilaksanakan saat panen, dengan mengumpulkan daun tanaman jagung dan memberikannya label. Daun yang diambil adalah daun yang sudah terbuka secara sempurna. Daun tersebut kemudian disimpan dalam plastik dan dimasukkan ke cool box untuk dibawa ke laboratorium.

\section{Analisis Data}

Rancangan yang digunakan adalah percobaan faktorial, dengan 2 perlakuan dan 3 ulangan, perlakuan pertama adalah sistem pertanaman jagung (monokultur dan agroforestri), dan varietas jagung. Penelitian ini menggunakan dua varietas jagung 
(varietas lokal dan varietas komersil). Masing-masing kombinasi perlakuan terdiri atas 24 tanaman, sehingga didapatkan \pm 288 tanaman jagung. Pengamatan pertumbuhan dan perkembangan jagung juga dilakukan, data produksi dan pertumbuhan jagung dianalisis menggunakan analisis varian, dan dilakukan uji lanjut menggunakan DMRT dengan $\alpha=0,05$.

\section{HASIL DAN PEMBAHASAN}

\section{Tinggi Tanaman Jagung}

Tinggi tanaman merupakan ukuran tanaman yang sering diamati sebagai indikator pertumbuhan maupun sebagai parameter untuk mengukur pengaruh lingkungan atau perlakuan yang diterapkan karena tinggi tanaman merupakan ukuran pertumbuhan yang paling mudah dilihat (Sitompul dan Guritno, 1995 cit Sinaga dan Amar, 2016).

Gambar 1. menunjukkan grafik pertumbuhan tinggi tanaman jagung. Pertumbuhan tinggi tanaman jagung menunjukkan adanya percepatan pertumbuhan pada saat 6 minggu masa tanam (mst), dan naik hingga tanaman memasuki fase generative. Pertumbuhan ini ditunjukkan oleh jagung yang di tanam di lahan monokultur maupun lahan gaharu.

Jagung ungu memiliki tinggi tanaman yang terendah dibandingkan dengan jagung kuning dan merah, ini dapat dilihat dari grafik dibawah, bahwa jagung ungu menunjukkan grafik yang terendah baik pada penanaman dilahan monokultur maupun dilahan gaharu. sedangkan penampakan jagung kuning menunjukkan tinggi tanaman yang tertinggi jika dibandingkan dengan kedua jagung pembanding lain (merah dan ungu), baik itu ditanam dilahan gaharu maupun dilahan monokultur.

Perlakuan penambahan pupuk pada pertanaman jagung dengan dosis yang berbeda, ternyata tidak memberikan hasil yang signifikan pada tinggi tanaman pada umur 8 minggu setelah tanam. Tinggi tanaman pada perlakuan tanpa pupuk, dengan berbagai tingkat dosis pupuk (pupuk PK, pupuk NP, pupuk NK, dan pupuk NPK) ternyata tidak berbeda nyata. Pemberian pupuk NK meningkatkan panjang akar jagung pada 
Novianty, L., Yunita, T.R. Pertumbuhan Dan Hasil Jagung ( Zea mays L.) Pada Sistem Agroforestri Dengan Gaharu (Aquilaria malaccensis) Di Desa Jaharun B, Kecamatan Galang, Kabupaten Deli Serdang, Sumtera Utara

umur $8 \mathrm{mst}$, dan berbeda nyata dengan tanaman yang diberi pupuk NP dan tanaman control (Sinaga dan Amar. 2016).

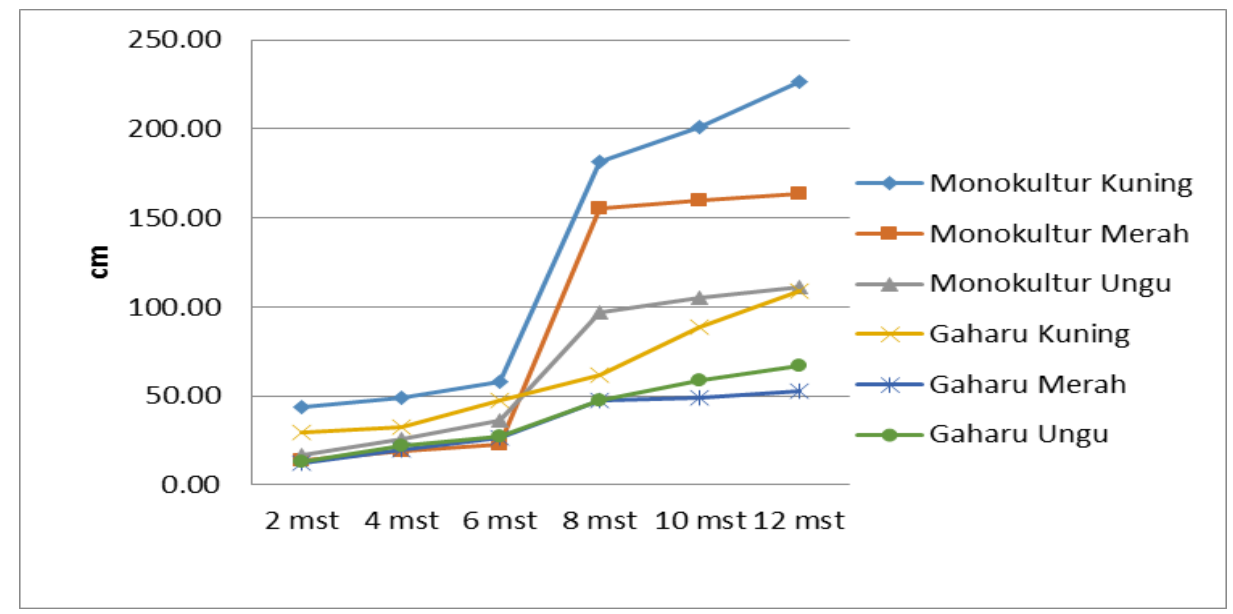

Gambar 1. Grafik pertumbuhan tinggi tanaman jagung

\section{Jumlah daun jagung}

Jumlah daun yang tertinggi ditunjukkan oleh tanaman jagung kuning diikuti oleh jagung ungu dan kemudian jagung merah dikedua lahan pengujian (lahan monokultur dan lahan gaharu). Peningkatan pertumbuhan jumlah daun ditunjukkan pada saat 8 minggu setelah tanam, ini dapat dilihat pada gambar 2. Jumlah daun jagung yang ditanam secara monokultur menunjukkan nilai yang tinggi jika dibandingkan dengan jumlah daun jagung yang dihasilkan pada penaman dilahan gaharu.

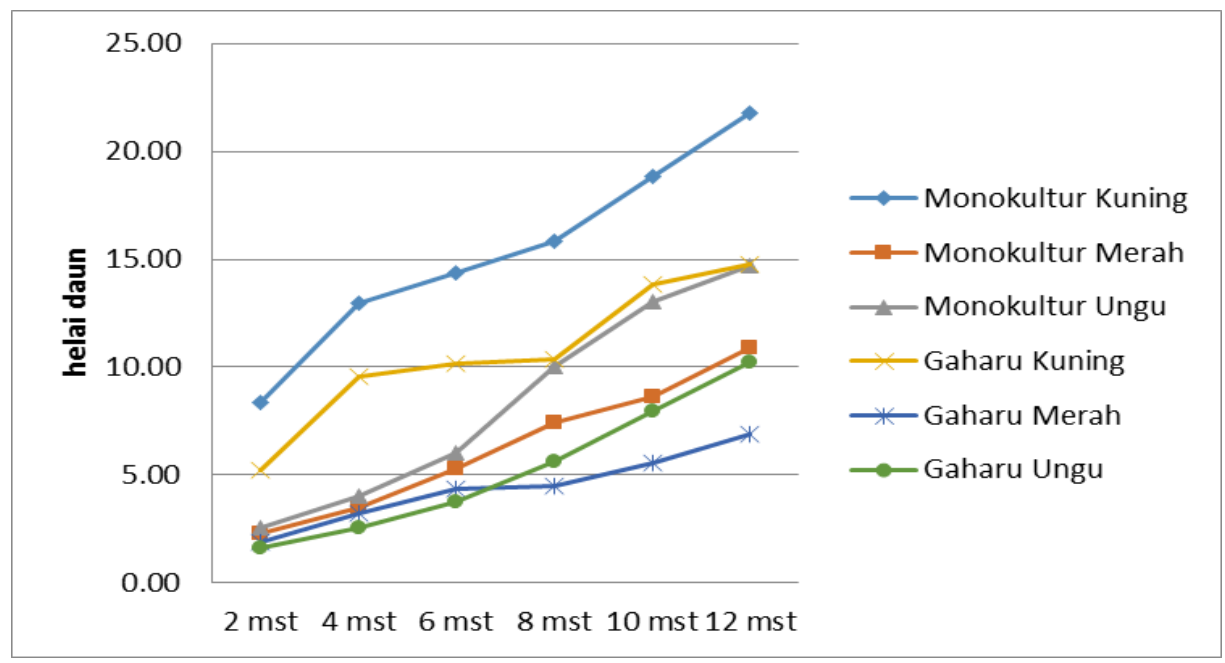

Gambar 2. Grafik jumlah daun

http://mahesainstitute.web.id/ojs2/index.php/Jons

(N)mahesainstitut@gmail.com

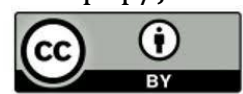

This work is licensed under a Creative Commons Attribution 4.0 


\section{Diameter batang jagung}

Ukuran diameter batang jagung yang tertinggi ditunjukkan oleh tanaman jagung kuning, baik ditanam dilahan monokultur maupun jagung yang ditanam dilahan gaharu, sedangkan nilai diameter batang jagung yang terendah terdapat pada jagung ungu baik dikedua lahan tersebut. Percepatan pertumbuhan diameter batang jagung ditemukan pada saat 6 mst, pola ini ditemukan pada jagung yang ditanamn dilahan monokultur maupun jagung yang ditanam di lahan gaharu. Hal ini dapat dilihat pada gambar 3.

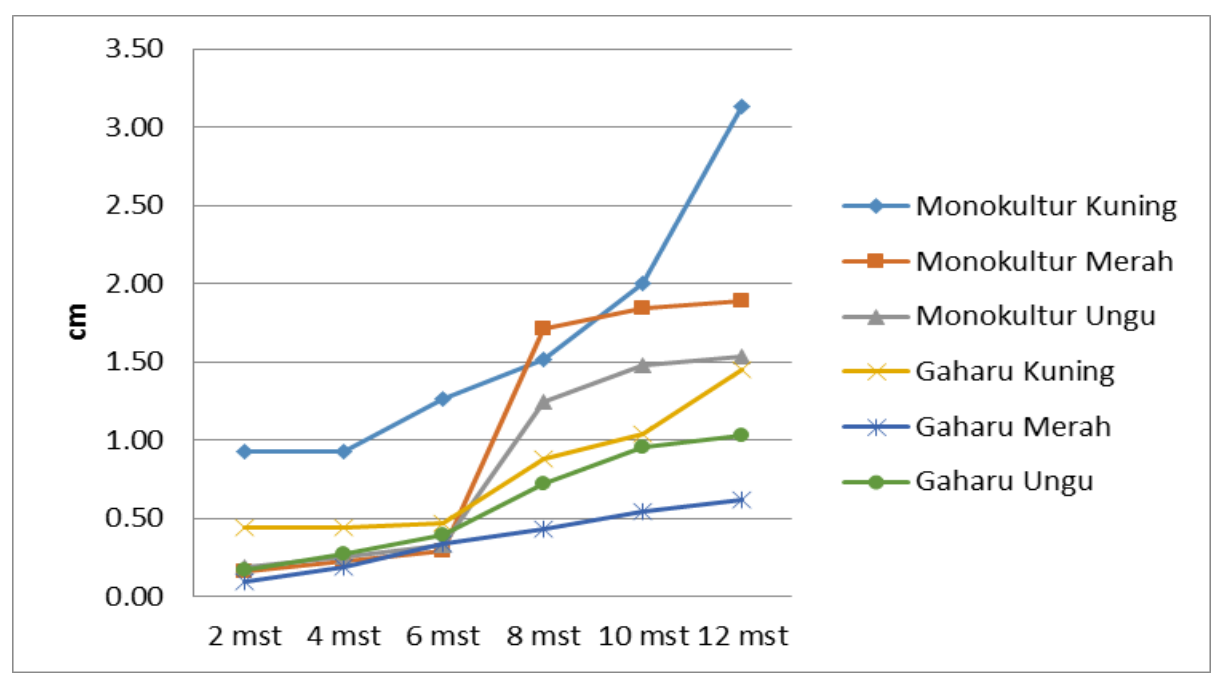

Gambar 3. Diameter batang jagung

Tabel 1. Rerata tinggi tanaman, jumlah daun, dan diameter batang jagung

\begin{tabular}{ccccc}
\hline Pola tanam & Jenis jagung & Tinggi tanaman & Jumlah daun & Diameter batang \\
\hline \multirow{3}{*}{ Monokultur } & Kuning & $181.204 \mathrm{a}$ & $15.833 \mathrm{a}$ & $1.521 \mathrm{a}$ \\
& Merah & $155.583 \mathrm{~b}$ & $7.435 \mathrm{c}$ & $1.709 \mathrm{a}$ \\
& Ungu & $96.879 \mathrm{c}$ & $10 \mathrm{~b}$ & $1.242 \mathrm{~b}$ \\
\multirow{3}{*}{ Gaharu } & Kuning & $61.767 \mathrm{~d}$ & $10.333 \mathrm{~b}$ & $0.877 \mathrm{c}$ \\
& Merah & $47.121 \mathrm{e}$ & $4.5 \mathrm{~d}$ & $0.433 \mathrm{~d}$ \\
& Ungu & $47.41 \mathrm{e}$ & $5.65 \mathrm{~d}$ & $0.724 \mathrm{c}$ \\
\hline
\end{tabular}

Angka yang diikuti oleh huruf yang sama dalam satu kolom tidak berbeda nyata pada taraf 0,5 DMRT

Jagung kuning yang ditanam dengan pola monokultur menunjukkan karakter tinggi tanaman, jumlah daun, dan diameter batang yang memiliki nilai terbesar dan berbeda nyata dengan tanaman jagung lain, baik yang ditanam secara monokultur maupun jagung yang 
ditanam dilahan gaharu (tabel 1). Sedangkan jagung kuning yang ditanam dilahan gaharu menunjukkan pertumbuhan tinggi tanaman, jumlah daun, dan diameter batang yang menurun dibandingkan dengan jagung kuning yang ditanam secara monokultur. Hal ini menunjukkan bahwa tanaman jagung yang ditanam dilahan garahu pertumbuhannya terganggu, dan tidak dapat tumbuh secara optimal. .

\section{Jaringan daun jagung}

Jaringan daun merupakan salah satu jaringan tumbuhan yang sangat produktif menghasilkan biomolekul bagi pertumbuhan jaringan tanaman, yang kemudian di translokasikan kembali ke jaringan tanaman lainnya (Nurahmi. 2010).

Hasil pengujian jaringan tanaman menunjukkan kandungan $\mathrm{N}$ yang terdapat pada daun tanaman jagung baik yang ditanam di lahan gaharu maupun monokultur menunjukkan nilai diatas batas kritis, yaitu > $2 \%$, sehingga tanaman jagung tidak kekurangan unsur $\mathrm{N}$, sedangkan pada tanaman yang mengalami defisiensi unsur $\mathrm{N}$ menunjukkan pertumbuhan yang lambat, kelihatan lemah, daunnya berwarna hijau terang hingga kuning. Biasa dijumpai pada daun-daun tua, karena N merupakan unsur yang mobile. Tanaman cenderung mudah stress terhadap kekeringan. Bila ammonium merupakan sumber N satu-satunya, kondisi toksik dapat berkembang yang ditunjukkan dengan patahnya batang, sehingga menghambat serapan air (Fahmi et al., 2010).

Table 2. Pengujian jaringan daun jagung

\begin{tabular}{ccccccc}
\hline Pola Tanam & Varietas Jagung & N (\%) & P (\%) & K (\%) & Na (\%) & Mg (\%) \\
\hline \multirow{3}{*}{ Monokultur Jagung } & Ungu & 2,18 & 0,344 & 2,92 & 0,16 & 0,35 \\
& Kuning & 2,28 & 0,512 & 1,91 & 0,19 & 0,46 \\
& Merah & 2,09 & 0,255 & 1,84 & 0,17 & 0,36 \\
\multirow{3}{*}{ Polikultur Gaharu } & Ungu & 2,37 & 0,323 & 2,90 & 0,18 & 0,20 \\
& Kuning & 2,12 & 0,319 & 4,57 & 0,15 & 0,28 \\
& Merah & 2,62 & 0,265 & 2,23 & 0,17 & 0,15 \\
\hline
\end{tabular}

Tabel 2. menunjukkan hasil pengujian jaringan tanaman jagung. Pada sebagaian besar unsur seperti unsur N, P, Na, dan Mg, tetapi pada unsur K menunjukkan hasil pengujian jaringan yang berbeda, unsur $\mathrm{K}$ pada pertanaman jagung lahan gaharu lebih 7 http://mahesainstitute.web.id/ojs2/index.php/Jons 
tinggi dari pada unsur K pada pertanaman jagung di lahan monokultur, terutama pada jagung kuning. Jagung kuning yang ditanam dilahan monokultur menunjukkan hasil unsur K 1,91\%, sedangkan pada pertanaman jagung di lahan gaharu menunjukan hasil unsur K 4,47\% hampir dua kali lipatnya.

Unsur $\mathrm{K}$ pada lahan monokultur menunjukkan angka yang rendah bila dibandingkan dengan batas kritis unsur K yaitu 2\%, sedangkan unsur Mg memiliki batas kritis sebesar 0,3\% tabel 4 (Fathan et al., 1988), nilai ini kurang dari hasil uji jaringan daun pada lahan gaharu $(0,15)$. Hal ini mungkin disebabkan oleh perbedaan lahan, sehingga mempengaruhi ketersedian hara serta kemampuan tanaman dalam menyerap hara.

Table 3. Batas kritis kekurangan hara dalam daun ke-5, 6, 7, dan saat silking (Fathan et al., 1988)

\begin{tabular}{cc}
\hline Hara tanaman & Batas kritis kekurangan hara \\
\hline $\mathrm{N}$ & $1.40 \%$ \\
$\mathrm{P}$ & $0.16 \%$ \\
$\mathrm{~K}$ & $2.00 \%$ \\
$\mathrm{~S}$ & $0.12 \%$ \\
$\mathrm{Ca}$ & $0.50 \%$ \\
$\mathrm{Mg}$ & $0.30 \%$ \\
$\mathrm{Fe}$ & $200 \mathrm{ppm}$ \\
$\mathrm{Zn}$ & $15 \mathrm{ppm}$ \\
\hline
\end{tabular}

Sedikit N, P, dan $\mathrm{K}$ diserap tanaman pada pertumbuhan fase 2 , dan serapan hara sangat cepat terjadi selama fase vegetatif dan pengisian biji. Unsur $\mathrm{N}$ dan $\mathrm{P}$ terusmenerus diserap tanaman sampai mendekati matang, sedangkan K terutama diperlukan saat silking. Sebagian besar N dan P dibawa ke titik tumbuh, batang, daun, dan bunga jantan, lalu dialihkan ke biji. Sebanyak 2/3-3/4 unsur K tertinggal di batang. Dengan demikian, $\mathrm{N}$ dan $\mathrm{P}$ terangkut dari tanah melalui biji saat panen, tetapi unsur hara $\mathrm{K}$ tidak (Akil. 2013).

Menurut Buckman and Brady (1969) unsur P mempunyai peranan sangat penting bagi tanaman jagung dalam proses respirasi, pemindahan dan penggunaan energi (ATPADP-AMP), pembelahan sel, pertumbuhan jaringan meristem, serta pembentukan 
bagian-bagian generatif seperti bunga dan buah. Penambahan unsur $\mathrm{P}$ melalui pemupukan harus berdasarkan pertimbanganpertimbangan tertentu seperti hasil uji tanah, tanaman, jenis pupuk.

Pendekatan target hasil didasarkan atas hasil penelitian bahwa respons tanaman terhadap pemupukan dan kesuburan tanah dari satu lokasi ke lokasi lainnya berbedabeda. Kemampuan tanah menyediakan hara alami (indigenous nutrient supply) dapat diduga melalui percobaan petak omisi (omision plot). Selisih antara hasil yang dipupuk lengkap NPK dengan hasil petak omisi (tanpa salah satu dari pupuk tersebut) menunjukkan besarnya kemampuan tanah menyuplai hara tersebut (Makka et al., 2008).

Pemberian pupuk ke dalam tanah bertujuan untuk menambah atau mempertahankan kesuburan tanah. Kesuburan tanah dinilai berdasarkan ketersediaan unsur hara di dalam tanah, baik hara makro maupun hara mikro secara berkecukupan dan berimbang (Bustami et al., 2012 cit Sinaga dan Amar. 2016).

Hara alami tanah dapat bersumber dari tanah, pupuk kandang, sisa tanaman, air hujan, udara bebas, dan air irigasi. Jadi pada prinsipnya jumlah pupuk atau hara yang diberikan pada tanaman jagung adalah jumlah pupuk yang diperlukan untuk memperoleh hasil pipilan kering yang dinginkan dikurangi dengan jumlah hara alami tanah. Kebutuhan pupuk N, P dan K untuk tanaman jagung pada tanah Ultisol Lampung dengan target hasil dari 7- 10 t ha-1 adalah $\mathrm{N}=125-200 \mathrm{~kg}$ ha-1 , P205 = 25-100 kg ha-1 dan K20 = 30-120 kg ha-1 (Makka. 2008).

Pertanaman jagung polikultur dengan gaharu (sistem agroforestry) menunjukkan pertumbuhan yang terganggu (tidak optimal) ditandai dengan tanaman jagung yang kerdil, dan tidak menghasilkan tongkol. Terdapat beberapa tanaman yang memproduksi bunga jantan dan betina, tetapi pertumbuhannya bunganya terganggu dan tidak terjadi pengisian biji. Jagung yang ditanam secara monokultur menghasilkan tongkol tetapi perkembangan bijinya tidak maksimal, berikut rerata berat tongkol pada jagung ungu adalah 207,5 g, sedangkan jagung merah sebesar 113,75 g, dan jagung kuning 103,75 g. 
Jagung yang ditanam di lahan gaharu menghasilkan bunga jantan (tongkol) dan bunga betina, tetapi perkembanganya tidak optimal dan tidak menghasilkan biji. Posisi tumbuhnya tongkol juga tidak normal, pada jagung ungu posisi tumbuhnya tongkol adalah diujung tanaman.

Terdapat tiga varietas jagung yang digunakan dalam penelitin ini yaitu: 1. Jagung IPB J1 (jagung ungu) merupakan benih jagung kualitas unggul cap Dramaga. Jagung ini cocok dibudidayakan di daerah dataran rendah hingga datara tinggi. Tanaman ini menghasilkan jagung dengan bulir berwarna hitam sementara batangnya berwarna merah. Panjang tongkolnya rata-rata $20 \mathrm{~cm}$. 2. Jagung IPB J2 (jagung merah) merupakan benih jagung kualitas unggul cap Dramaga. Jagung ini cocok dibudidayakan di daerah dataran rendah hingga dataran tinggi. Tanaman ini menghasilkan jagung dengan bulir berwarna ungu kemerahan sementara batangnya berwarna merah. Panjang tongkolnya rata-rata $20 \mathrm{~cm}$. 3. Jagung Bonanza F1 (jagung kuning) merupakan benih jagung produksi PT EWSI panah merah. Jagung ini merupkan jagung hibrida.

\section{SIMPULAN}

Pertumbuhan dan perkembangan jagung di lahan gaharu tidak optimal. Rata-rata pertambahan tinggi tanaman, jumlah daun, dan diameter batang yang tertinggi ditunjukkan oleh jagung yang ditanam secara monokultur pada masing-masing kultivar. Penggunaan 3 varietas jagung pada agroforestri tanaman gaharu umur 3 tahun menghasilkan produksi yang tidak berbeda nyata dari produksi pada pola tanam monokultur.

\section{DAFTAR PUSTAKA}

Akil M. (2013). Kebutuhan Hara N, P, dan K Tanaman Jagung HIbrida Pada Lahan Kering di Kabupaten Gowa. Seminar Nasional Serealia.

[BPS] Badan Pusat Statistik. (2015). Produksi padi, jagung, dan kedelai. [internet]. [diunduh 2017 Juni 02].Tersediaipada: http://www.bps.go.id/brs_file/aram_01jul13.pdf

Buckman, H.O. and N.C. Brady. (1969). The Nature and Properties of Soil. The Macmillan Company. New York. Diterjemahkan oleh Soegiman. 1982. Ilmu Tanah. Bhratara Karya Aksara. Jakarta Abdurachman, A. Saridan dan I. Lanniari, 2009. Potensi dan Riap Diameter Jenis 44 Lamk di Hutan 
Novianty, L., Yunita, T.R. Pertumbuhan Dan Hasil Jagung ( Zea mays L.) Pada Sistem Agroforestri Dengan Gaharu (Aquilaria malaccensis) Di Desa Jaharun B, Kecamatan Galang, Kabupaten Deli Serdang, Sumtera Utara

Hutan Alam Labanan, Kabupaten Berau, Kalimanatan Timur. Jurnal Penelitian Hutan dan Konservasi Alam (P3HKA) Vol.VI. No.1 tahun 2009. Bogor

Fahmi A., Syamsudin, Sri Nuryani H. Utami, dan Bostang Radjagukguk. (2010). Pengaruh Interaksi Hara Nitrogen dan Fosfor Terhadap Pertumbuhan Tanaman Jagung (Zea mays L) Pada Tanah Regosol dan Latosol. Berita Biologi 10 (3).

Makka A. Murni. (2008). Menentukan Kebutuhan Nitrogen, Fosfor, dan Kalium Untuk Tanaman Jagung Berdasarkan Target Hasil dan Efisiensi Agronomik Pada Lahan Kering Ultisol Lampung. Jurnal Tanah dan Lingkungan, Vol 10 No 2. 46-49.

Makka Andarias Murni. (2008). Menentukan Kebutuhan Nitrogen, Fosfor dan Kalium Untuk Tanaman Jaugung Berdasarkan Target Hasil dan Efisiensi Agronomik Pada Lahan Kering Ultisol Lampung. Jurnal Tanah dan Lingkungan. Vol 10 No. 2.

Nurahmi E. (2010). Kandungan Unsur Hara Tanah dan Tanaman Selada Pada Tanah Bekas Tsunami Akibat Pemberian Pupuk Organik dan Anorganik. J. Floratek 5: 74-85.

Prasetyo. (2004). Budidaya kapulaga sebagai tanaman sela pada tegakan sengon. Jurnal Ilmu- Ilmu Pertanian Indonesia. 6(1): 22-31.

Sinaga A, dan Amar Ma'ruf. (2016). Tanggapan Hasil Pertumbuhan Tanaman Jagung Akibat Pemberian Pupuk Urea, SP-36 dan KCL. Jurnal Pertanian BERNAS, Volume 12 No 3.

Thyrida E. Silaban, Edison Purba, dan Jasmani Ginting. (2013). Pertumbuhan dan Produksi Jagung Manis (Zea mays sacaratha Sturt. L) pada Berbagai Jarak Tanam dan Waktu Olah Tanah. Jurnal Online Agroteknologi USU 1(3). 